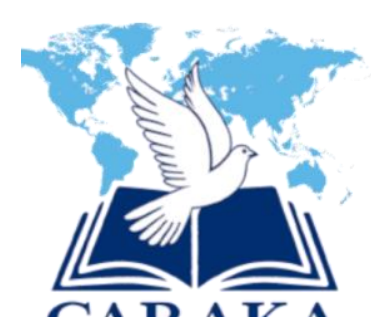

\title{
Peran Khotbah Gembala Sidang Dalam Pertumbuhan Rohani Jemaat Menurut John Chrysostom
}

\author{
Hisikia Gulo, Hendi \\ Sekolah Tinggi Teologi Soteria Purwokerto \\ hiskiagulo27@gmail.com \\ hendi@sttsoteria.ac.id
}

\begin{abstract}
The preaching role of the pastor of the congregation in the spiritual growth of the congregation has a major contribution to the salvation of every soul. This article discusses and describes the role of the pastor as a preacher in the spiritual growth of the church taught by John Chrysostom. Every pastor as a preacher must reach 3 depths of approach to preaching the word of God; Cognitive, Affective and Psychomotor. It is through the preaching of the word of God which is taught by a pastor so that someone understands and understands the meaning of following and imitating the great shepherd, Jesus Christ, and carrying out each of His teachings. The spiritual growth of each congregation is influenced by each pastor's role as the preaching of the word of God through 3 depth approaches with the aim of the need for the purity of one's soul leading to spiritual maturity.
\end{abstract}

Key Words: Pastor; Maturity; Role; Preacher.

\begin{abstract}
Abstrak
Peran khotbah gembala sidang dalam pertumbuhan rohani jemaat memiliki kontribusi besar bagi keselamatan setiap jiwa. Artikel ini membahas dan menguraikan peran gembala sidang sebagai pengkhotbah dalam pertumbuhan rohani jemaat yang di ajarkan oleh John Chrysostom. Setiap gembala sidang sebagai pengkhotbah harus mencapai 3 kedalaman pendekatan pemberitaan firman Allah; Kognitif, Afektif dan Psikomotorik. Melalui pemberitaan firman Allah yang di ajarkan oleh seorang gembala sidang sehingga seseorang mengerti dan memahami arti dari mengikut dan meneladani gembala agung yaitu Yesus Kristus serta melakukan setiap ajaran-Nya. Pertumbuhan rohani setiap jemaat di pengaruhi dari setiap peran gembala sidang sebagai pemberitaan firman Allah melalui 3 kedalaman pendekatan dengan tujuan kebutuhan akan kemurnian jiwa seseorang menuju kepada kedewasaan rohani.
\end{abstract}

Kata-kata Kunci: Gembala Sidang; Kedewasaan; Peran; Pengkhotbah. 


\section{PENDAHULUAN}

Para Bapa gereja sebagai penjaga utama dari ajaran para rasul mengajarkan bahwa firman Tuhan bertujuan untuk menyembuhkan luka keberdosaan seseorang. Kebenaran firman Tuhan, baik yang disampaikan di hadapan umum maupun secara pribadi, bertujuan untuk menyembuhkan luka keberdosaan seseorang; bukan sebaliknya membuat seseorang semakin menjauh dari Allah. Hanya kekuatan Allah yang dapat membawa kebenaran firman-Nya kepada setiap hati manusia. ${ }^{1}$ Sehingga batin inilah yang harus disembuhkan atau di obati oleh Allah melalui firman-Nya. Yesus berkata bahwa dari dalam hati timbul segala pikiran jahat (Matius 15:19) dan dosa sehingga untuk mengobati batin hanya ada satu cara dengan belajar pada Kristus. Mulai dari kerja Nous ${ }^{2}$ dengan berdoa kepada Roh Kudus sehingga Roh Kudus mencurahkan pikiran Kristus ke dalam batin melalui belajar akan firman Allah. Hal tersebut mengindikasikan bahwa gembala sidang hadir untuk melayani dan memberikan penanganan yang berguna dan tepat bagi batin seseorang yang sedang mati akibat dosa (Efesus 2:1).

Gembala sidang sebagai wakil Allah di dunia memiliki kontribusi besar bagi keselamatan jiwa setiap umat manusia, dan hal ini dapat di wujudkan melalui pelayanan akan firman Allah dalam bentuk khotbah yang dijalankan oleh para pelayan gereja atau gembala sidang gereja. ${ }^{3}$ Dalam penelitian Dwi Setio Budiono Santoso mengatakan khotbah yang meliputi pendahuluan, nats Alkitab, makna dan aplikasi memengaruhi pertumbuhan kerohanian jemaat. ${ }^{4}$ Namun dalam artikel ini, penulis sepakat dengan John Chrysostom yang menekankan bahwa khotbah dari seorang gembala sidang dalam pertumbuhan rohani jemaat tidak hanya melihat pendahuluan, nats Alkitab, makna dan aplikasi bagi jemaat saja. Akan tetapi harus mencapai tiga level kedalaman. Pertama, level kognitif. Kedua, level afektif dan Ketiga, level psikomotorik.

Seorang gembala sidang yang baik harus memahami keadaan domba-dombanya yang memiliki kebutuhan yang berbeda, karena pada prinsipnya Allah menciptakan manusia dengan perbedaan begitu pula dengan kebutuhannya. Namun tak dapat di pungkiri, pada saat ini para gembala sidang masih mempunyai pemahaman yang sangat terbatas tentang pentingnya peran seorang gembala sidang dalam memberitakan firman Allah yang tepat sehingga kurang memahami hal tersebut. Dampaknya datang berbagai masalah yang terjadi dalam gereja akibat kurangnya peran seorang gembala sidang dalam mendidik akan kebenaran firman Allah.

\footnotetext{
${ }^{1}$ Hendi dan Syelin Umur, "Strategi Pelayanan Pastoral Bagi Kaum Awam Menurut Bapa Gereja Gregorius Agung" Fidei: Jurnal Teologi Sistematika dan Praktika 3, no. 1 (2020): 57.

${ }^{2}$ Istilah Nous adalah bagian jiwa yang paling murni, mata jiwa manusia.

${ }^{3}$ Ibid, 38.

${ }^{4}$ Dwi Setio Budiono Santoso, "Peran Khotbah Gembala Sidang dalam Pertumbuhan Rohani Jemaat," Magnum Opus: Jurnal Teologi dan Kepemimpinan Kristen 1, no. 2 (2020): 96.
} 
Penjelasan di atas perlu di sikapi secara serius, sebab jika di abaikan akan mempengaruhi pertumbuhan rohani seseorang bahkan lebih buruk lagi meninggalkan imannya. Seorang gembala sidang tidak cukup hanya memiliki pengetahuan dalam berkhotbah tetapi juga memiliki keterampilan dalam mempraktikkan proses pembimbingan seseorang dalam pengenalannya akan Kristus. ${ }^{5}$ Oleh sebab itu, seorang gembala sidang hadir terutama dalam menyampaikan firman Allah sehingga mencapai sasaran yaitu untuk mendewasakan iman seseorang akan pengenalan di dalam Yesus Kristus. Seorang Bapa Gereja yang bernama John Chrysostom dalam bukunya berjudul The Christian Priesthood telah memberi perhatian khusus terhadap masalah di atas. Bukunya menjadi ulasan penulis di dalam artikel ini sehingga para pembaca, terutama para gembala sidang, dapat melaksanakan peran dan tanggung jawabnya dengan baik sebagai pengantara umat khususnya dalam pemberitaan firman Allah.

John Chrysostom lahir di Antiokhia pada tahun 347 dari keluarga seorang komandan militer. John belajar di bawah para filsuf dan ahli retorika terbaik. Tetapi kemudian dia mengabaikan displin ilmu sekuler yang sia-sia, hierarki masa depan ini beralih ke studi mendalam tentang Kitab Suci dan perenungan doa. St. Meletius, Uskup Antiokhia (12 Februari), mengasihi Yohanes seperti putranya sendiri, membimbingnya dalam iman, dan pada tahun 367 di baptis. Pada tahun 386 John ditahbiskan menjadi presbyter atau penatua oleh Uskup Flavian dari Antiokhia. John adalah seorang pengkhotbah yang berpengaruh, dan katakatanya yang di ilhami menjuluki dia "Mulut Emas" (Chrysostom). ${ }^{6}$ Selama dua belas tahun John berkhotbah di gereja, biasanya dua kali seminggu, tetapi kadang-kadang setiap hari, dan sangat menggerakkan hati para pendengarnya. Hasilnya, dalam semangat penggembalaannya untuk mengajar orang Kristen akan pemahaman yang lebih baik tentang Kitab Suci, John menggunakan hermeneutika, suatu penafsiran dan analisis terhadap firman Allah (Eksegesis). Di antara karya-karya eksegesisnya adalah seluruh Kitab Suci (Kejadian, Mazmur, Injil Matius dan Yohanes, serta surat-surat Rasul Paulus), dan juga banyak homili tentang teks-teks tersendiri dari Kitab Suci, tentang hari-hari perayaan, peringatan orang-orang kudus, dan juga homili-homili yang bersifat apologetis (membela diri) (melawan orang-orang Anomoea, orang Yudais dan orang-orang yang tidak percaya). ${ }^{7}$ Bagaimana seorang gembala sidang menjalankan pelayanan pengembalaannya, Chrysostom menyatakan ada 3 hal pendekatan yang harus di mengerti dan lakukan oleh seorang gembala sidang dalam menjalankan pelayanan pastoral sebagai pemberita firman Allah.

\footnotetext{
5 John Chrysostom. The Christian Priesthood (New York: Vladimir's Seminary Press, 1984, 39.

${ }^{6} \mathrm{Https}$ //www.oca.org/saints/lives/2020/11/13/103292-saint-john-chrysostom-archbishop-ofconstantinople, diakses 20 Juli 2020.

${ }^{7} \mathrm{Https} / / /$ hendisttrii.wordpress.com/2020/06/16/john-chrysostom-347/, diakses 20 Juli 2020. 


\section{METODE PENELITIAN}

Tulisan ini menggunakan metode penelitian literatur. Penulis menggunakan buku The Christian Priesthood sebagai landasan teori dalam membahas peran khotbah gembala sidang dalam pertumbuhan rohani jemaat. Penulis membahas tentang 3 pendekatan yang harus di lakukan sebagai pengkhotbah, serta pentingnya firman Allah sebagai kebutuhan akan kemurnian jiwa. Penjelasan ini kemudian di jabarkan melalui interaksi dengan teks-teks lain di dalam Alkitab dan berbagai sumber sekunder yang mendukung.

\section{HASIL DAN PEMBAHASAN}

\section{Pengertian Gembala Sidang}

Gembala sidang merupakan seorang pemimpin yang bertanggung jawab untuk melakukan tugas penggembalaan yang selalu erat kaitannya dengan pertumbuhan kerohanian jemaat. ${ }^{8}$ Gembala sidang harus bisa memelihara domba-domba Allah. Ia harus berusaha untuk melayani orang lain, bukan untuk dilayani. Istilah gembala menunjuk pada seseorang yang bertugas dan bertanggung jawab untuk memelihara ternak. Pengistilahan ini dihubungkan dengan diri Yesus Kristus dan karya-Nya sebagai gembala sejati atau gembala yang baik (Yohanes 10). Ungkapan ini mengacu pada pelayanan Yesus yang tanpa pamrih bersedia memberikan pertolongan dan pengasuhan terhadap para pengikut-Nya diharapkan dapat mengambil sikap dan pelayanan Yesus ini dalam kehidupan praktis mereka. Tuhan Yesus adalah Gembala Agung (1 Petrus 5:4). Gembala sidang adalah pribadi yang dipercayakan oleh Tuhan dalam mendidik, membimbing, mengajar dan membawa jemaat kepada pengenalan firman Tuhan yang menuju pada satu tujuan adalah bertumbuh ke arah Dia secara sempurna (Efesus 4:11-16). ${ }^{9}$ Jadi, dapat di simpulkan bahwa gembala sidang adalah seseorang yang bertugas sebagai pemimpin rohani untuk memelihara, melindungi serta menumbuhkan iman percaya bagi setiap jemaat Tuhan akan pengenalan Yesus Kristus.

\section{Pertumbuhan Rohani Jemaat}

Pertumbuhan rohani adalah proses seseorang menjadi semakin serupa dan segambar dengan Yesus Kristus. Firman Tuhan yang di beritakan oleh gembala sidang sangat esensial bagi pertumbuhan rohani jemaat sebab Allah menyingkapi seluruh kehendak-Nya kepada jemaat melalui Kitab Suci atau firman Tuhan yang di sampaikan gembala sidang. ${ }^{10}$ Ketika orang percaya menempatkan imannya kepada Yesus, maka Roh Kudus memulai proses menjadikan seseorang semakin serupa dengan Dia, menjadikan manusia sama dengan gambar-

\footnotetext{
${ }^{8}$ Arozatulo Telaumbanua, "Peran Gembala Sidang Sebagai Pendidik Dalam Pertumbuhan Rohani Jemaat," Fidei: Jurnal Teologi Sistematika Dan Praktika 2, no. 2 (2019): 367.

${ }^{9}$ Ibid, 365.

${ }^{10}$ Chrysostom, 87.
} 
Nya. Pertumbuhan rohani itu proses seumur hidup, yang terjadi melalui proses mempelajari dan menerapkan firman Tuhan (2 Timotius 3:16-17), dan berjalan bersama Roh (Galatia 5:1626). Pertumbuhan rohani orang percaya adalah satu-satunya bagaimana orang percaya dibawa kepada Yesus Kristus. Apa yang diwartakan itulah yang mempunyai pengaruh yang signifikan bagi pertumbuhan rohani pribadi jemaat, yaitu membawa manusia kepada suatu progresitas iman yang selalu berorientasi kepada Yesus Kristus. ${ }^{11}$ Hal ini menekankan bahwa kontribusi gembala sidang sebagai pemberitaan firman Tuhan bagi pertumbuhan rohani jemaat adalah hal yang utama dan terutama karena ini kebutuhan bagi keselamatan dan kemurnian jiwa orang supaya semakin mengenal dan memproses hidup jemaat semakin serupa dan segambar dengan Kristus.

Seorang gembala sidang sebagai pengkhotbah bertanggung jawab penuh untuk memberitakan kebenaran firman Tuhan kepada semua manusia, tanpa dibatasi oleh ruang dan waktu, dan hal ini bukan hanya terbatas di gereja ataupun di kegiatan-kegiatan rutinitas gerejawi. ${ }^{12}$ Oleh karena tanggung jawab penggembalaan merupakan panggilan mulia. Hal ini dikarenakan tanggung jawab menjadi gembala sidang bersumber dari panggilan Allah. ${ }^{13}$ Maka khotbah yang disampaikan oleh gembala sidang dalam memberitakan firman Tuhan harus mempunya fondasi yang kuat karena menyangkut kebutuhan pertumbuhan rohani jemaat. Artinya kebenaran firman Tuhan yang disampaikan oleh seorang gembala sidang mempunyai peranan penting dalam segala segi aspek pertumbuhan rohani jemaat. Dengan demikian, ketika seseorang telah menjaga hubungan intim dengan Tuhan atau membangun kerohanian yang baik, maka segala sesuatu dapat berjalan dengan baik karena ikut campur tangan Tuhan. ${ }^{14} \mathrm{Hal}$ inilah yang menyebabkan begitu penting bagi seorang gembala sidang memiliki fondasi yang kuat dan tahu apa yang semestinya di ajarkan bagi pertumbuhan rohani jemaat karena fondasi dari iman Kekristenan adalah Yesus Kristus karena segala sesuatu berasal dari Dia (1 Korintus 3:11). Oleh karena itu yang diberitakan oleh seorang gembala sidang adalah Kristus Sang firman Allah.

Dalam berkhotbah atau mengajarkan firman Tuhan kepada setiap kawanan domba Kristus harus di dasarkan oleh Kristus sebagai dasar dari iman Kristen sebab ini adalah kebutuhan yang sangat fundamental yang dapat menyelamatkan setiap jiwa orang percaya. ${ }^{15}$ Dengan cara menjalani purification atau pemurnian jiwa di dalam diri manusia di mana ketika seseorang percaya mendengarkan khotbah atau firman Tuhan yang diberitakan oleh gembala

\footnotetext{
${ }^{11}$ Telaumbanua, 368 .

12 Ibid, 371.

${ }^{13}$ Sara L. Sapan dan Dicky Dominggus, "Tanggung jawab Penggembalaan berdasarkan Perspektif 1 Petrus 5:1-4," Jurnal Teologi Amreta 3, no. 2 (2020): 142.

${ }^{14}$ Minggus Dilla, "Kajian Biblikal Spiritualitas Hamba Tuhan Berdasarkan 2 Timotius 2:1-13," Manna Rafflesia 3, no. 1 (2016): 99.

${ }^{15}$ Chrysostom, 42.
} 
sidang dia mulai memproses diri dari gambar Allah menuju kepada rupa Allah artinya manusia kembali kepada kodrat asli sebagai ciptaan Allah yang paling mulia. Hal ini akan diperoleh pada saat theosis nantinya jadi haruslah manusia memiliki iman, pengharapan dan kasih didalam kehidupan setiap manusia (1 Korintus 13:12-13) sesuai rencana Agung Allah. Hendi menjelaskan bahwa di dalam Grand Design of God manusia sekarang haruslah sedang menjalankan purification atau pemurnian melalui Christ Event (Filipi 2:12-17). ${ }^{16}$ Jadi gembala sidang di dalam memberitakan firman Tuhan bagi pertumbuhan iman jemaat harus benarbenar memahami fondasi dari iman Kristen dan apa yang harus mereka yakini sehingga melalui siapa Yesus dan inkarnasi-Nya manusia pun terus-menerus mengerjakan keselamatan untuk dirinya secara personal dan meresponi keselamatan dengan iman yang disebut dengan keselamatan personal.

Di dalam permurnian jiwa manusia hal ini di kerjakan manusia agar dapat bertumbuh ke arah Kristus yang adalah rupa Allah. ${ }^{17}$ Firman Allah yang di ajarkan gembala sidang sebagai pengkhotbah adalah benar-benar memurnikan jiwa setiap orang karena menyangkut keselamatan setiap jiwa manusia. Ketika orang percaya yang hidup di dalam Kristus telah menjalani purification dimana manusia lama telah mengenakan pakaian Kristus sehingga seseorang menjadi manusia baru yang akan diperbaharui secara terus-menerus (Kolose 3:10), yang harus diperbaharui adalah tubuh dan daging yang harus melawan dosa sehingga menjadi sempurna. ${ }^{18}$ Allah memberikan mandat kepada pengkhotbah atau gembala sidang lewat pimpinan Roh Kudus untuk memberitakan kebenaran firman Tuhan bagi pertumbuhan rohani jemaat supaya orang percaya semakin mengenal Dia. Dan orang yang semakin mengenal siapa dirinya dan Allah yang dia sembah adalah orang yang sudah ditebus melalui kematian, penyaliban dan kebangkitan Kristus sehingga Dia terus memproses kemanusiaan lamanya menjadi manusia baru yang hidup di dalam Kristus.

Manusia baru adalah manusia yang di ciptakan menurut Allah di dalam kebenaran dan kekudusan yang sebenarnya yang kemudian dijelaskan dalam satu rangkaian konsekuensi di dalamnya yaitu pemurnian jiwa dan tubuh dalam wujud perbuatan-perbuatan baik dalam melawan hawa nafsu. ${ }^{19}$ Setiap orang akan bertumbuh ke arah Kristus menjadi dewasa seperti Kristus (Efesus 4:13,15) sehingga pada akhirnya manusia baru akan menjadi serupa dengan Kristus (1 Yohanes 3:2). Di dalam Kristus setiap orang percaya terus menyempurnakan manusia baru melalui pengudusan sampai dia menerima keselamatan yang seutuhnya di dalam Dia (Efesus 4:13; 1:14; Roma 6:22; Kolose 3:10). Hal ini menekankan bahwa gembala sidang

\footnotetext{
${ }^{16}$ Ibid, 56.

${ }^{17}$ Ibid, 43 .

18 Ibid, 44.

${ }^{19}$ Hendi dan Tiopan Aruan, "Konsep Manusia Baru Di Dalam Kristus Berdasarkan Surat Efesus 4:1732” Evangelikal: Jurnal Teologi Injili dan Pembinaan Warga Jemaat, 4, no. 1 (2020): 120.
} 
sebagai pemberita firman Tuhan harus benar-benar menyentuh kebutuhan setiap kawanan domba Kristus sampai mengalami kekuatan dan kedasyatan Allah yang Agung melalui pemberitaan kebenaran firman Allah.

\section{Tiga Pendekatan Khotbah Menurut John Chrysostom}

\section{Level Kognitif (Pengetahuan)}

Hendi menjelaskan bahwa Nous dan Logos (manifestasi dari Nous seperti kognitif atau pemahaman seseorang) akan belajar firman Allah sehingga memahami isi hati Allah yang terdapat di dalam firman-Nya. Kognitif atau otak seseorang mendapatkan konsep atau ide melalui interaksi Nous dan Logos dengan firman Allah. ${ }^{20}$ Kemampuan berpikir atau kognitif menyatakan tingkat kecerdasan seorang gembala sidang dalam menyampaikan firman Allah. Gembala sidang sebagai pemberita firman Tuhan, dalam memenuhi panggilannya, juga harus meningkatkan kemampuannya dalam berbicara di depan umum agar dapat menyampaikan pesan Tuhan secara efektif kepada jemaat sebagai penerimanya.

Hal ini menegaskan bahwa seorang gembala sidang ketika menyampaikan kebenaran firman Allah harus memiliki pengetahuan tentang doktrin (didaskalia) yang sehat dan juga harus bertanggung jawab atas iman seseorang (2 Timotius 3:15-17). Dalam Orthodox Christian, Jesus Christ is the Truth (John 14:6), and because the Truth is a Person, truth cannot be relativized. ${ }^{21}$ Yesus adalah kebenaran dan kehidupan yang harus di sampaikan kepada tiap-tiap orang percaya. Dalam memberitakan firman pun, seorang gembala sidang harus mengetahui akan doktrin yang absolut sebab yang di beritakan oleh gembala sidang adalah pribadi Kristus sendiri. Dasar dan acuan khotbah adalah pernyataan Allah didalam diri Yesus Kristus sebagaimana disaksikan di dalam Kitab Suci. Dan Kitab Suci adalah satusatunya sumber tertulis yang masih ada tentang Yesus Kristus. Sehingga Alkitablah yang menjadi acuan untuk berkhotbah. Dimana Firman Allah yang ketahui dari Alkitab menjadi tolok ukur gembala sidang dalam mempersaksikan firman yang hidup yakni Yesus Kristus. Maka Chrysostom menekankan di level kognitif seorang gembala sidang dalam menyampaikan firman Allah dalam bentuk khotbah ada beberapa syarat; Pertama, bertanggung jawab secara hermeneutika, Kedua, memberitakan kebenaran dari Allah bukan menyenangkan manusia semata, Ketiga, mempunyai struktur khotbah yang jelas, Keempat, Christ Centered sebagai dasar khotbah dalam memberitakan firman Tuhan. ${ }^{22}$

${ }^{20}$ Hendi, Formasi Rohani: Fondasi, Purifikasi \& Deifikasi (Yogyakarta: LeutikaPrio, 2019), 331.

${ }^{21}$ Andrew Stephen Damick, Orthodoxy and Heterodoxy: Finding the Way to Christ in a Complicated Religious Landscape (America: A Division of Ancient Faith Ministries, 2017), 28.

${ }^{22}$ Chrysostom, 33. 
Mengajar kebenaran firman Tuhan mutlak di lakukan oleh gembala sidang untuk menjawab kebutuhan jemaat Tuhan. Kelaparan rohani mereka akan di penuhi dengan makanan yang tidak sehat jika gembala sidang tidak menyediakan makanan yang sehat bagi kawanan domba-Nya Kristus. ${ }^{23}$ Hal ini menekankan bahwa seorang gembala sidang harus benar-benar memiliki ajaran atau doktrin tentang Kristus, oleh karena isinya Kitab Suci adalah Kristus, maka ketika belajar Kitab suci berarti menemukan sosok atau pribadi Kristus yang tertulis bukan sekedar konsep teoritis tentang Kristus. ${ }^{24}$ Rasul Paulus bahkan menegaskan "Awasilah dirimu sendiri dan awasilah ajaranmu” (1 Timotius 4:16). Hal ini menegaskan bahwa seorang gembala sidang dalam menjalani kehidupan ini adalah sama pentingnya apa yang dia ajarkan dan pegang sebagai ajaran yang sehat serta dipraktekkan. Ketika seorang gembala sidang dalam menyampaikan firman Allah harus dapat menyakini bahwa firman yang dia sampaikan kepada jemaat adalah benar-benar doktrin yang sehat. Hendi mengatakan ajaran yang disampaikan harus Christ-Centered berarti ajaran didaskalia yang berpusat kepada Kristus. Di didaskalia Kristus dan di lanjutkan dalam bentuk paradosis gereja merupakan warisan kekayaan didaskalia atau doktrin yang begitu berharga dan berlimpah bagi kekristenan sampai hari ini. ${ }^{25}$

Gembala sidang dalam hal menyampaikan firman Allah harus mempunyai pengetahuan dan pemahaman yang memadai tentang Kitab Suci. Yosafat Bangun menjelaskan bahwa tidak dapat di sangkal bahwa kemurnian doktrin dan pengajaran yang baik menjadi salah satu penyebab dan pendorong pertumbuhan rohani jemaat Tuhan. ${ }^{26}$ Hal ini menegaskan bahwa apabila seorang gembala sidang harus memiliki pengajaran yang kokoh dan solid berarti dapat melindungi setiap umat dalam berbagai ajaran yang menyesatkan. Bahkan di jelaskan oleh Sunarto dalam penelitiannya bahwa pemberita firman yang berintegritas ia tidak terpengaruh oleh pemberita firman yang palsu. ${ }^{27}$ Artinya seorang gembala sidang dalam memberitakan firman Allah harus dengan penuh keyakinan dan pengetahuan yang memadai, sebab integritas sangat penting ketika menyangkut pelayanan dan pemberitaan firman Tuhan. ${ }^{28}$

Dengan demikian seorang gembala sidang harus mampu mengajarkan nilai-nilai yang terkandung di dalam Kitab Suci yang pada akhirnya membawa seseorang kepada Kristus. Sehingga setiap orang percaya tidak boleh menjadi serupa dengan dunia ini tetapi memperbarui Nous secara terus-menerus dengan cara mempelajari firman Allah setiap hari.

${ }^{23}$ Benijanto Sugihono, A Call of A Shepherd (Yogyakarta: ANDI, 2009), 49.

${ }^{24}$ Hendi, Inspirasi Kalbu 3 (Yogyakarta: LeutikaPrio, 2019), 3.

25 Ibid, 217.

${ }^{26}$ Yosafat Bangun, Integritas Pemimpin Pastoral (Yogyakarta: Andi, 2010), 43.

${ }^{27}$ Sunarto, "Integritas Seorang Pengkhotbah dan Kualitas Khotbah Dalam Pemberitaan Firman Tuhan," Jurnal Te Deum 7, no. 1 (2017): 81.

${ }^{28}$ Markus Sudjarwo, "Mengaplikasikan Integritas Gembala Jemaat menurut Surat-surat Penggembalaan" Jurnal Epigraphe 3, no. 2 (2019): 176. 
Hal ini dapat terwujud apabila seorang gembala sidang mengetahui dan mengenal doktrin yang benar. Sebab doktrin inilah menjadi pendorong setiap umat ke dalam pertumbuhan rohani akan pengenalan Yesus Kristus.

\section{Level Afektif (Spiritual)}

Pemahaman seseorang di level kognitif harus diturunkan ke hati karena di situlah konsep atau pemahaman seseorang akan firman Allah di matangkan atau dijiwai atau dihayati. Khotbah merupakan tempat bertemunya jemaat dengan Allah, dan pengkhotbah dengan segala apa yang dipersiapkan berusaha menyalurkan kasih karunia Allah kepada jemaat, sehingga jemaat yang sedang mengalami kelemahan rohani dikuatkan kembali dan semakin kokoh di dalam Yesus Kristus. ${ }^{29}$

Di dalam hati inilah pikiran atau Nous setiap orang berjumpa dengan Allah dan mendengarkan Dia secara pribadi apa yang menjadi keinginan Allah terhadap pemahaman firman Allah yang sudah dipelajari. ${ }^{30}$ Dalam penggembalaan pun seorang gembala sidang harus mempunyai pengalaman-pengalaman spiritual bersama dengan Allah. Hidup yang bergaul dengan Allah itu di bangun atas pengenalan dan relasi pribadi, yaitu relasi yang di bangun antara pribadi Allah dan pribadi orang percaya. ${ }^{31}$ Setiap orang percaya harus memahami bahwa Allah adalah kasih. Oleh karena kasih-Nya, Allah menciptakan manusia supaya Dia dapat berbagi kasih kepada ciptaan-Nya, sehingga manusia mengagumkan Dia yang adalah kasih. ${ }^{32}$ Dengan percaya dan beriman kepada Yesus Kristus sebagai Tuhan dan Juruselamat yang telah menebus dosa-dosa dunia dan yang telah bangkit, maka para pemimpin rohani menerima karunia Roh, yaitu Roh Kudus tinggal di dalam kehidupan mereka. ${ }^{33}$ Jadi, seorang gembala sidang di dasari oleh iman yang tertuju kepada satu pribadi yaitu Yesus Kristus.

Kehidupan seorang gembala sidang harus didasarkan pada karya Roh Kudus yang diterima dan tinggal di dalam hidup orang beriman, maka spiritualitas dan hidup mereka yang lama diperbarui. Mereka memiliki hidup yang baru yang berada di dalam kasih Allah. Tugas seorang gembala sidang dalam memberitakan Injil sangat penting dan memberi pengaruh yang besar dalam pertumbuhan rohani jemaat karena apa yang disampaikan oleh gembala sidang

${ }^{29}$ Adelius Waruwu, Junior Natan Silalahi, Haposan Siahaan, Abraham Johannis, "Korelasi Khotbah Ekspositori dan Antusias Jemaat dalam Beribadah di GBI Mawar Sharon Cileungsi," Caraka: Jurnal Teologi Biblika dan Praktika 1, no. 1 (2020): 54.

${ }^{30}$ Hendi, Inspirasi Kalbu, 331.

${ }^{31}$ Alfius Areng Mutak, "Reposisi Hati: Memahami Panggilan dan Dinamika Spiritualitas Hamba Tuhan," Jurnal Theologi Aletheia 16, no. 1 (2014): 64.

${ }^{32}$ Hiskia Gulo, “Konsep Pencobaan Menurut Yakobus 1:12-15,” Bonafide: Jurnal Teologi dan Pendidikan Kristen 1, no. 2 (2020): 174.

${ }^{33}$ Dorus Dolfinus Buinei, "Menerapkan Kualifikasi Kepemimpinan Hamba menurut Injil Markus bagi Gembala Sidang GPdI Wilayah Waropen Barat, Papua” Jurnal Epigraphe 4, no. 1 (2020): 25. 
dalam khotbah tidak akan lepas dari bagaimana kuasa Tuhan yang bekerja dan terjadi dalam kehidupan orang percaya. ${ }^{34}$ Bahkan Chrysostom menambahkan bahwa seorang gembala harus mempunyai mata rohani yang tajam dan juga pengalaman rohani (Spiritual kepada Allah) yang bisa melihat perubahan hidup setiap orang yang sudah di beritakan kebenaran firman Tuhan. ${ }^{35}$ Seorang gembala sidang telah memberikan makanan kognitif bagi setiap umat melalui khotbah atau pemberitaan firman Allah. Maka gembala sidang harus menjadikan sebagai nilai spiritual yang dapat menuntun setiap umat kepada keselamatan. Relasi yang intim bersama dengan Tuhan menunjukkan tingkat kedewasaan spiritualitas seseorang. Relasi yang intim bersama Tuhan menunjukkan ketergantungan seorang pengkhotbah akan jati diri di hadapan-Nya, bahwa ia seorang pemberita firman-Nya bukan berita tentang pribadinya sendiri.

Pelayanan seorang gembala sidang sebagai pemberitaan firman adalah suatu keharusan bagi seorang gembala bagi orang lain untuk menuntun seseorang menyesali akan segala perbuatan dosa yang tidak sesuai dengan kehendak Allah dengan sungguh-sungguh bertobat sesudah mendengar kabar baik (Injil). Tujuan dari khotbah adalah tidak lain dari membawa seseorang kepada pemahaman akan keadaan diri sendiri sehingga mengalami suatu perubahan yang membawa mereka kepada firman Allah oleh karena di terangi firman sehingga menuntun mereka kepada jalan kebenaran Allah. Memberi tuntunan berarti mengajar, mengarahkan, dan menujukkan jalan yang sesuai dengan kebenaran firman Tuhan. ${ }^{36}$ Memberitakan firman Allah pun bukan hanya sekedar menceritakan kisah-kisah yang ada di dalam Kitab suci tetapi lebih dari pada itu ada nilai spiritual yang menuntun seseorang kepada Kristus dan dapat memperoleh anugerah keselamatan karena sudah di terangi oleh firman Allah.

Pelayanan seorang gembala sidang sebagai pemberita firman kepada setiap orang tanpa mengetahui setiap nilai spiritual yang terkandung pada setiap teks Kitab Suci, maka manusia tidak dapat datang kepada Injil dan kepada Sang penyembuh dari batin. Sebab kebenaran dan keselamatan tidak dapat temukan seseorang dalam dirinya sendiri. ${ }^{37} \mathrm{Hal}$ ini menegaskan bahwa tugas seorang gembala sidang dalam memberitakan Injil sangat penting dan memberi pengaruh yang besar dalam pertumbuhan rohani jemaat karena apa yang disampaikan oleh gembala sidang dalam khotbah tidak akan lepas dari bagaimana kuasa Tuhan yang bekerja dan terjadi dalam kehidupan orang percaya. ${ }^{38}$

\footnotetext{
${ }^{34}$ Hendi, Inspirasi Kalbu, 370

${ }^{35}$ Chrysostom, 42.

${ }^{36}$ Ibid, 50.

${ }^{37}$ Ibid, 52.

${ }^{38}$ Ibid, 370.
} 


\section{Level Psikomotorik (Moral)}

Pada level ini Roh Kudus akan menuntun hati ini supaya roh seseorang menguasai tubuh dan menggerakkan seluruh kekuatan atau daya tubuh untuk melakukan keinginan Roh yang ada di dalam hati tadi. Artinya bagaimana khotbah yang di sampaikan oleh pemberita firman menjadi perbuatan setiap orang yang mendengarkan atau jemaat Tuhan. tanggung jawab pribadi pengkhotbah tidak berhenti kepada tanggung jawab spiritualitas saja, tetapi secara holistik kepada karakter pribadinya Karakter pengkhotbah merupakan bagian yang penting dalam berkhotbah. ${ }^{39}$ Sebab kebenaran Firman Tuhan yang telah disampaikan kepada jemaat dapat menambah kekuatan rohani maupun keyakinan setiap anggota. Jemaat dapat bertumbuh dalam pengenalan akan Tuhan Yesus dan tidak bimbang dalam mengatasi setiap pergumulan atau pun kondisi kehidupan yang terjadi hari lepas hari dalam kehidupan. ${ }^{40}$ Iman termanifestasi dalam perbuatan sehingga iman ini menjadi hidup. Di sinilah kasih kepada Allah dengan segenap hati, pikiran, jiwa, dan kekuatan terwujud.

Chrysostom mengatakan bahwa di level moral berbicara bagaimana orang percaya menerapkan atau melakukan firman itu dalam kehidupan sehari-hari sehingga menjadi terampil dan gaya hidup orang percaya. Yesus mengajarkan untuk mengasihi Allah dengan segenap hati, jiwa, pikiran, dan kekuatan. Seorang hamba Tuhan haruslah siap memiliki standar moral, kesalehan, kesucian, memiliki pergaulan yang akrab dengan Allah. Dalam pergaulannya dengan jemaat, sekitarnya, ia harus menunjukkan buah-buah Roh yang nyata dalam hidup setiap hari, juga menjadi teladan dalam segala kehidupan. ${ }^{41}$ Gembala sidang bukan hanya memberitakan firman dan mengajar tetapi juga menerima firman dalam arti menghidupi akan doktrin, agar pemberitaan firman Tuhan juga dapat dibangun dan diteguhkan oleh iman sehingga dapat mewujudkan iman yang hidup dalam perbuatan baik. ${ }^{42}$

Seorang gembala sidang adalah orang yang benar-benar bisa memberikan teladan hidup bagi setiap kawanan domba yang di beri makan oleh firman Allah. Rasul Paulus mengingatkan Timotius supaya dapat menjadi teladan bagi orang-orang percaya dalam perkataanmu, dalam tingkah lakumu, dalam kasihmu, dalam kesetiaanmu dan dalam kesucianmu. Paulus meminta Timotius untuk menjadi tupos (teladan, contoh, pola bagi gembala sidang dalam (1 Timotus 4:12). Istilah tupos yang Paulus pakai pada ayat 12 yang ia kaitan dengan kata ginou $=$ jadilah sehingga membentuk kalimat imperaktif yang dikenakan kepada Timotius. Timotius diminta agar menjadi teladan bagi sidang sekalipun ia muda. ${ }^{43}$

\footnotetext{
${ }^{39}$ Ibid, 90.

${ }^{40}$ Ibid, 54

${ }^{41}$ Bernike Sihombing, "Kepribadian dan Kehidupan Hamba Tuhan Menurut 1 Timotius 3:1-13" Kurios: Jurnal Teologi dan Pendidikan Agama Kristen 2, no. 1 (2014): 3.

${ }^{42}$ Chrysostom, 50.

${ }^{43}$ Ibid, 180.
} 
Memberi teladan berarti sosok pribadi yang dapat di tiru untuk di contoh tentang perbuatan, kelakuan dan sifatnya. Kehidupan seorang gembala sidang adalah sebuah cermin yang dapat memantulkan nilai-nilai firman Allah yang ingin diikuti pengikut atau kawanan domba-Nya Kristus.

Seorang gembala sidang menjadi pemimpin rohani, harus dapat diteladani melalui sikap hidup dan perkataan karena kehidupan umat Kristiani selalu disorot dalam segala arah. ${ }^{44}$ Rasul Paulus sebagai Rasul Kristus berulang kali menasihati Timotius supaya dapat mengikuti teladan Paulus (1 Korintus 4:16). Sebelum membangun kerohanian jemaat agar menjadi dewasa, seorang gembala harus mampu membangun dirinya sendiri terlebih dahulu. Jika hal ini dilakukannya, maka ia akan bisa membangun hubungan yang erat dengan para jemaatnya. Bahkan, ia juga bisa mendorong jemaat untuk belajar kebenaran firman Tuhan, mengenal kebenaran dan melakukannya dengan baik. ${ }^{45}$ Hal ini menegaskan bahwa gembala sidang yang berperan sebagai seorang pengkhotbah atau pemberita firman Allah harus mampu menjadi contoh dan teladan hidup kepada jemaat dalam segala aspek kehidupannya.

Setiap pendengar akan kebenaran firman Allah pasti merindukan kemurnian dari para gembala sidang sebagai pengkhotbah sebab ini adalah kebutuhan yang dapat menyelamatkan jiwa setiap manusia. Chrysostom menyatakan gembala sidang bertanggung jawab atas jiwa kawanan domba Kristus. Seorang gembala sidang harus memiliki jiwa yang mampu menerangi jiwa jemaatnya bagi pertumbuhan rohani. ${ }^{46}$ Seorang gembala sidang bukan hanya sekedar membawa, mengajar, namun mampu membawa kawanan domba kepada Allah. Sebab untuk menarik dekat dengan Allah ialah harus dengan penuh kesucian. Namun seorang gembala sidang harus tetap menjaga dirinya tetap hidup kudus di hadapan Allah. Seorang gembala sidang membutuhkan kekudusan yang jauh lebih besar dari pada jemaat atau kawanan domba yang dia pelihara, bina dan pimpin kepada Yesus Kristus. ${ }^{47}$

Gembala sidang adalah orang yang dapat membawa jemaat untuk dekat dengan Allah sehingga di tuntun untuk kudus di hadapan Allah. Hal ini menekankan bahwa gembala sidang adalah figur atau sosok yang dapat di teladani oleh domba-dombanya mulai dari kehidupan rohani dan gaya hidup sehari-hari sehingga apa yang dia katakan benar-benar dia hidupi dan alami serta apa yang dia sampaikan benar-benar doktrin yang benar (sehat) sesuai dengan ajaran Yesus Kristus yang di teruskan oleh Para Rasul Kristus.

\footnotetext{
${ }^{44}$ Ibid, 373.

45 Ibid, 187.

${ }^{46}$ Ibid, 42.

${ }^{47}$ Ibid, 45 .
} 


\section{KESIMPULAN}

Jemaat yang bertumbuh adalah jemaat yang memiliki kesanggupan mendengar dan mengaplikasikan firman Tuhan yang di sampaikan oleh gembala sidang. Bukan hanya sekedar mendengar saja, tetapi mempraktekkan dalam kehidupan sehari-hari, sehingga akan berakar, bertumbuh dan berbuah di dalam Yesus Kristus. Gembala sidang dalam memberitakan firman Tuhan pun merupakan tugas dan mandat yang di percayakan Allah bagi gembala sidang oleh bimbingan dan tuntunan Roh Kudus serta ketetapan Allah yang memberikan kontribusi besar bagi pertumbuhan rohani setiap jemaat Kristus. Khotbah dari gembala sidang tidak hanya menerapkan kebenaran Allah secara pribadi namun Roh Kudus juga menerapkan kebenaran itu melalui cara-cara yang baru kepada para pendengarnya yaitu orang percaya.

Gembala sidang sebagai pengkhotbah atau pemberita firman Allah, harus mampu memberikan pengaruh terhadap pertumbuhan rohani jemaat melalui pengajaran firman Tuhan sehingga menumbuhkan dan menyempurnakan iman orang percaya. Khotbah dari seorang gembala sidang yang baik, dia harus menjadi teladan sebagai pemberita firman atau pengkhotbah yang melayani banyak orang percaya. Firman Allah mempunyai otoritas tinggi bagi pertumbuhan rohani jemaat atau kawanan domba-Nya Kristus. Kristus adalah hati Kitab Suci, pusat ibadah gerejawi, dan model kemanusiaan yang menjadi tujuan akhir manusia. Gembala sidang dengan senantiasa mempercayakan diri kepada Roh Kudus yang berkuasa untuk menciptakan pemberitaan firman atau khotbah sebagai sarana untuk menciptakan kehidupan yang baru serta menuju kepada kedewasaan dan kesempurnaan hidup bersama dengan Yesus Kristus.

\section{DAFTAR PUSTAKA}

Bangun, Yosafat. Integritas Pemimpin Pastoral. Yogyakarta: Andi, 2010.

Buinei, Dorus Dolfinus. "Menerapkan Kualifikasi Kepemimpinan Hamba menurut Injil Markus bagi Gembala Sidang GPdI Wilayah Waropen Barat, Papua" Jurnal Epigraphe 4, no. 1 (2020): 18-30.

Chrysostom, John. The Christian Priesthood. New York: Vladimir's Seminary Press, 1984.

Damick, Andrew Stephen. Orthodoxy and Heterodoxy: Finding the Way to Christ in a Complicated Religious Landscape. America: A Division of Ancient Faith Ministries, 2017.

Dilla, Minggus. "Kajian Biblikal Spiritualitas Hamba Tuhan Berdasarkan 2 Timotius 2:1-13," Manna Rafflesia 3, no. 1 (2016): 76-101.

Gulo, Hiskia. "Konsep Pencobaan Menurut Yakobus 1:12-15," Bonafide: Jurnal Teologi dan Pendidikan Kristen 1, no. 2 (2020): 165-179.

Hendi dan Tiopan Aruan. "Konsep Manusia Baru Di Dalam Kristus Berdasarkan Surat Efesus 4:17-32. Evangelikal: Jurnal Teologi Injili dan Pembinaan Warga Jemaat 4, no. 1 (2020): 113-130.

Hendi dan Syelin Umur. "Strategi Pelayanan Pastoral Bagi Kaum Awam Menurut Bapa Gereja Gregorius Agung” Fidei: Jurnal Teologi Sistematika dan Praktika 3, no. 1 (2020): 37-61. 
Hendi. Formasi Rohani: Fondasi, Purifikasi \& Deifikasi. Yogyakarta: LeutikaPrio, 2019. Inspirasi Kalbu 3. Yogyakarta: LeutikaPrio, 2019.

Mutak, Alfius Areng. "Reposisi Hati: Memahami Panggilan dan Dinamika Spiritualitas Hamba Tuhan," Jurnal Theologi Aletheia 16, no. 1 (2014): 46-65.

Santoso, Dwi Setio Budiono "Peran Khotbah Gembala Sidang dalam Pertumbuhan Rohani Jemaat," Magnum Opus: Jurnal Teologi dan Kepemimpinan Kristen 1, no. 2 (2020): 8896.

Sapan, Sapan. L dan Dicky Dominggus, “Tanggung jawab Penggembalaan berdasarkan Perspektif 1 Petrus 5:1-4,” Jurnal Teologi Amreta 3, no. 2 (2020): 124-145.

Sihombing, Bernike. "Kepribadian dan Kehidupan Hamba Tuhan Menurut 1 Timotius 3:1-13" Kurios: Jurnal Teologi dan Pendidikan Agama Kristen 2, no. 1 (2014): 1-19.

Sudjarwo, Markus. "Mengaplikasikan Integritas Gembala Jemaat menurut Surat-surat Penggembalaan" Jurnal Epigraphe 3, no. 2 (2019): 173-189.

Sugihono, Benijanto. A Call of A Shepherd. Yogyakarta: Andi, 2009.

Sunarto, "Integritas Seorang Pengkhotbah dan Kualitas Khotbah Dalam Pemberitaan Firman Tuhan” Jurnal Te Deum 7, no. 1 (2017): 77-98.

Telaumbanua, Arozatulo, "Peran Gembala Sidang Sebagai Pendidik Dalam Pertumbuhan Rohani Jemaat, Fidei: Jurnal Teologi Sistematika Dan Praktika 2, no. 2 (2019): 362387.

Waruwu. Adelius, Junior Natan Silalahi, Haposan Siahaan, Abraham Johannis, "Korelasi Khotbah Ekspositori dan Antusias Jemaat dalam Beribadah di GBI Mawar Sharon Cileungsi," Caraka: Jurnal Teologi Biblika dan Praktika 1, no. 1 (2020): 52-64.

Https://hendisttrii.wordpress.com/2020/06/16/john-chrysostom-347/, diakses 20 Juli 2020. Https://www.oca.org/saints/lives/2020/11/13/103292-saint-john-chrysostom-archbishop-ofconstantinople, diakses 20 Juli 2020. 